\title{
FINIS: Objects of the End of Time, Afterlife Writing and Situation of Graves
}

\author{
Jane Wildgoose
}

King's College London

\section{ABSTRACT}

Focusing on Hogarth's last graphic work, The Bathos, this essay examines the ways in which the vanitas themes it represents are bound up with events that occurred towards the end of the artist's life. Drawing on life writing (including elements of Hogarth's autobiographical notes) that accompanied the cataloguing of his works in the years following his death, it discusses a number of controversies that drew scathing criticism of his work, his character, his politics, his ideas about English art and his standing as an artist, during his final years. Focusing on textual and visual images employed by Hogarth's detractors to belittle him, it explores how these metaphors may be connected with the iconography he employed in The Bathos, and the extent to which the work may be 'read' as a representation of the artist himself, and his view of his reputation at the end of his career. Contrasting the pessimistic image Hogarth presents in his final work with the afterlife writing of his achievements by his contemporaries, it concludes with reflection on the role that his grave continues to play in celebrating his life and his status as one of the most talented and innovative artists of the eighteenth century.

Keywords: Hogarth, Bathos, grave, afterlife

In her work on writing the lives of British painters of the eighteenth century, Karen Junod notes that William Hogarth (1697-1764) 'was the first English painter to receive major and relentless biographical coverage after his death, in October $1764{ }^{1}{ }^{1}$ Collecting his work became so popular 
that the term 'Hogarthomania', coined by the Shakespearean scholar Edmund Malone (1741-1812) seventeen years after the artist's death, describes a period of hectic acquisition of, and inflated prices for, Hogarth's printed works from the late 1760s until the 1830s "when there was a general slump in the art market'. ${ }^{2}$

While these factors make Hogarth an interesting candidate for consideration when exploring themes of life writing and death, I was unaware of them when we selected the print ${ }^{3}$ - known variously as 'FINIS' and as Tail Piece: The Bathos, or, Manner of Sinking, in Sublime Paintings, inscribed to the Dealers in Dark Pictures - as the image to accompany the publicity for the Dialogues of the Dead: A Day of Exploration of Life Writing and Death conference at King's College London, in 2018. ${ }^{4}$ I would turn to The Bathos when I began preparing my paper for the closing session of the day, which was dedicated to objects, life writing and death.

I approached the print with a view to discussing its symbolism as a preface to introducing my practice as an artist/researcher and Keeper of my own specialist 'library' of objects and books dedicated to memory and remembrance. ${ }^{5}$ Examining the range of objects Hogarth included in The Bathos, and thinking about them in relation to the writing of his life, I was intrigued to learn that the print was the last work the artist produced, approximately six months before he died. Conscious that I am not a Hogarth scholar and that my line of enquiry into the print would be a departure from my usual fields of research, I decided to follow Junod's lead and refer to one of Hogarth's earliest biographers, John Ireland ( $d .1808)$, who published a two-volume catalogue of the artist's prints entitled Hogarth Illustrated in 1791, which was reprinted in 1793 and 1806 .

After the death in 1789 of Hogarth's widow Jane ('who seems to have offered all encouragement' to the production of Hogarth Illustrated), Ireland obtained a number of the artist's autobiographical notes and sketches, which he used as the basis for a biography that was published in 1798 (with later editions in 1804 and 1812) as a supplement to the earlier work. ${ }^{6}$ This would become recognised, according to Ireland's own entry in the $D N B$ a century later, as 'the foundation for all subsequent memoirs' of the artist. ${ }^{7}$ As Hogarth's more recent biographer, Ronald Paulson, observes, the artist's autobiographical notes, made during the final year of his life, reveal that ' $[\mathrm{h}] \mathrm{e}$ understood that what he had to say about contemporary English art was inextricably bound up with his own life'. ${ }^{8}$

This essay discusses Hogarth's last graphic work and the ways in which it 'was inextricably bound up with' events that occurred at the end of his life. Drawing on life writing (including elements of the artist's 
autobiographical notes) that accompanied the cataloguing of his works in the years following his death, it discusses a number of controversies that drew scathing criticism of his work, his character, his politics, his ideas about English art and his standing as an artist during the final years of his life. Focusing on textual and visual images employed by his detractors to belittle him, this essay explores how these metaphors may be connected with the depiction of 'every object which denoted the end of time', in The Bathos, ${ }^{9}$ and reflects on the extent to which the work may be 'read' as a representation of the artist himself, and his view of his situation at the end of his career.

Contrasting the pessimistic image Hogarth presents in his final work with the afterlife writing of his achievements by his contemporaries, this essay also considers the role that his grave continues to play in celebrating his life, and his status as one of the most 'witty, satirical, subversive [...] hugely talented [and] innovative artists of the eighteenth century' in 'the memory of posterity'. ${ }^{10}$ In conclusion, it reflects on how (as Ken Worpole argues), "[1] andscapes of the dead are also landscapes of the living, [and] it is this coterminousness of life and death that gives the burial site its salience and emotional power.' ${ }^{11}$

\section{THE FINIS}

Ireland, a great admirer and collector of Hogarth's work, writes in the opening of the final chapter of Hogarth Illustrated that he has, in front of him, a copy of 'the last plate that Hogarth engraved, which is properly denominated THE FINIS to that great painter's works'. ${ }^{12}$ Ireland recounts a story about the work's production that would be repeated in numerous late eighteenth- and early nineteenth-century collections of Hogarth's works-most of which included some form of writing about the artist's life. He tells us that, while dining with friends some time in early 1764 , Hogarth was asked what would be the subject of his next print, to which he replied, "'THE END OF ALL THINGS!"' When one of his friends suggested that, "[i]f that should be the case [...] your business will be finished, for there will be an end of the painter', Hogarth, '[w] ith a look that conveyed a consciousness of approaching dissolution, and a deep sigh $[\ldots]$ answered, "There will so; $[s i c]$ and therefore, the sooner my work is done the better". ${ }^{13}$

According to Ireland, Hogarth began work on The Bathos the next day, and seemed 'to consider it as A TERMINUS TO HIS FAME', in which he would 'bring together every object which denoted the end of time, and throw a ridicule upon the bathos and profundity of the ancient masters'. ${ }^{14}$ 


\section{THE BATHOS AND ITS DEBT TO PERI BATHOUS}

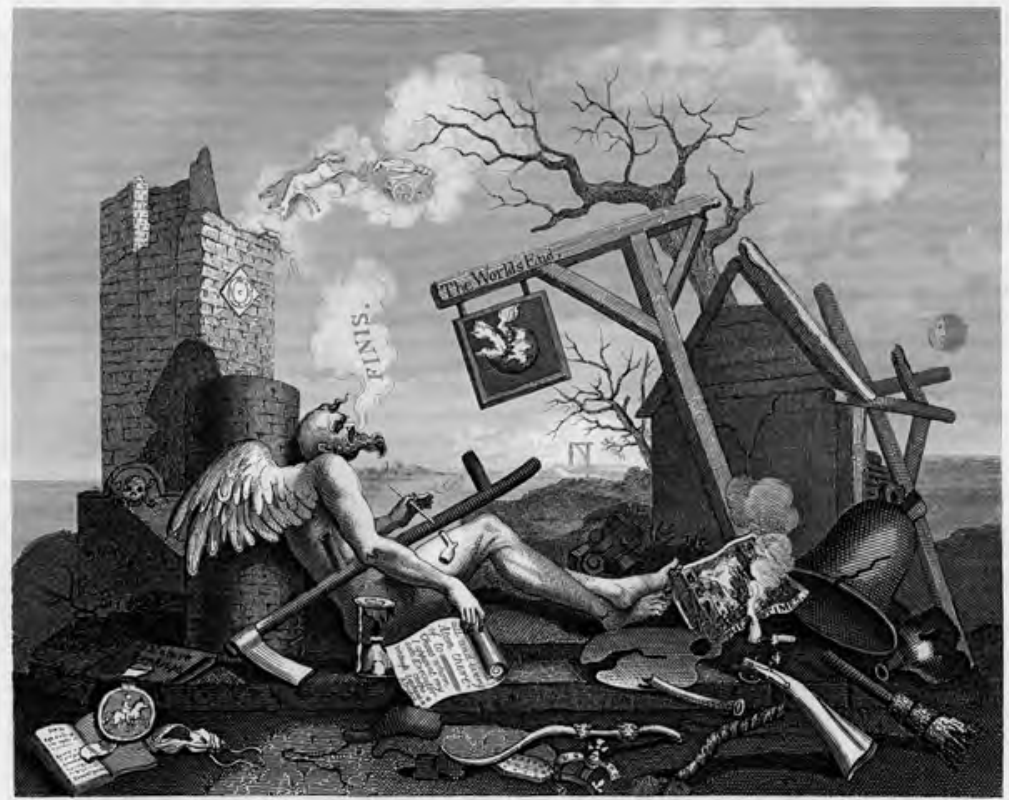

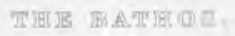

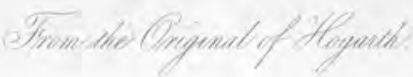

Fig. 1 William Hogarth, The Bathos, 1764

( $19^{\text {th }}$-century reproduction 'From the Original of Hogarth')

(c) Jane Wildgoose, The Wildgoose Memorial Library

The version of The Bathos that we used for publicity for the Dialogues of the Dead conference was taken from a nineteenth-century print 'from the original of Hogarth' in my own collection, The Wildgoose Memorial Library (Fig. 1). It is simply entitled The Bathos, but prints made from Hogarth's original plate in the eighteenth century included the words 'TAIL PIECE' at the top, with 'THE BATHOS' and the subtitle 'or, Manner of Sinking, in Sublime Paintings, inscribed to the Dealers in Dark Pictures' in cursive script beneath the image (Fig. 2). 


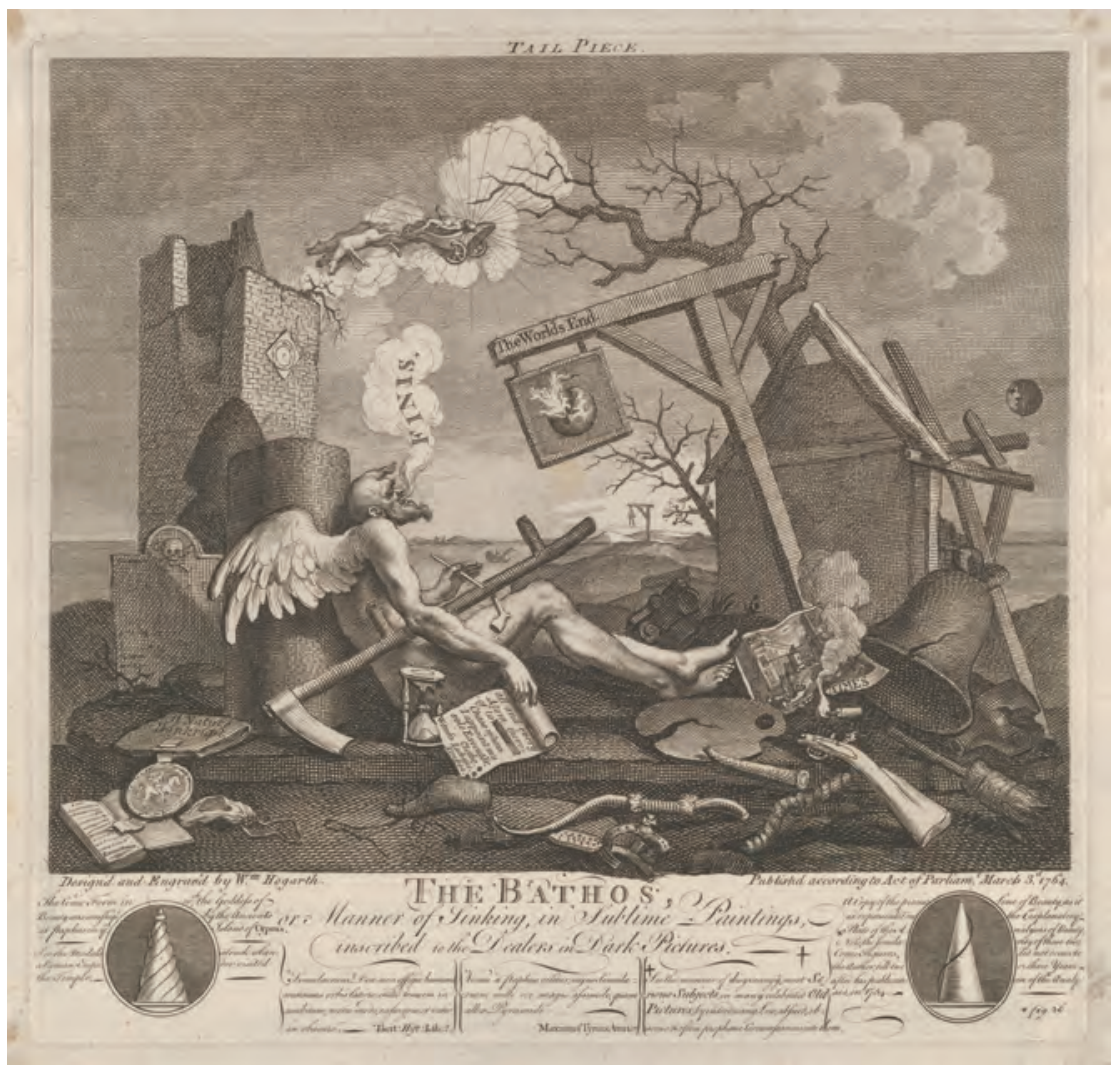

Fig. 2 William Hogarth, Tail Piece, or The Bathos, March 3, 1764 Metropolitan Museum of Art (Public Domain)

As numerous commentators (including Ireland, John Trusler and John Nichols in the eighteenth century, and Ronald Paulson and David Bindman in our own time) observe, Hogarth's subtitle is an allusion to an essay entitled Peri Bathous: The Art of Sinking in Poetry (1727). A work generally attributed to Alexander Pope (1688-1744), Peri Bathous is also understood to be a product of the satirical Scriblerus Club, which included Pope, Jonathan Swift (1667-1745) and the Scottish physician and satirist Dr. John Arbuthnot (1667-1735) — all of whom produced work under the pseudonym Martinus Scriblerus. ${ }^{15}$

Peri Bathous: The Art of Sinking in Poetry parodies a classical treatise on the Sublime by Longinus, using extravagant irony to lampoon the 
pretensions and perceived failings of contemporary fellow writers. ${ }^{16}$ According to the $O E D$, the rhetorical use of the term 'bathos' to describe a 'ludicrous descent from the elevated to the commonplace in writing or speech' has its origin in this essay, while initially deriving from the Greek word for 'depth, lowest phase, bottom'.

In his discussion of The Bathos, Ireland makes knowing reference to Martinus Scriblerus and the Peri Bathous; quoting at length from the book, he concludes that The Bathos

is well worthy of the title, for a more heterogeneous compound of ludicrous and serious objects was never displayed in one print. Some of his images the artist has gleaned from the common field of the poor company of punsters; and for others, hath soared into the airy regions of mythological allegory. He ascends from an inch of candle setting fire to a print, to the chariot of the sun, which, with Apollo Pan, and his three fiery coursers, sinks into endless night. ${ }^{17}$

\section{AN INCH OF CANDLE SETTING FIRE TO A PRINT}

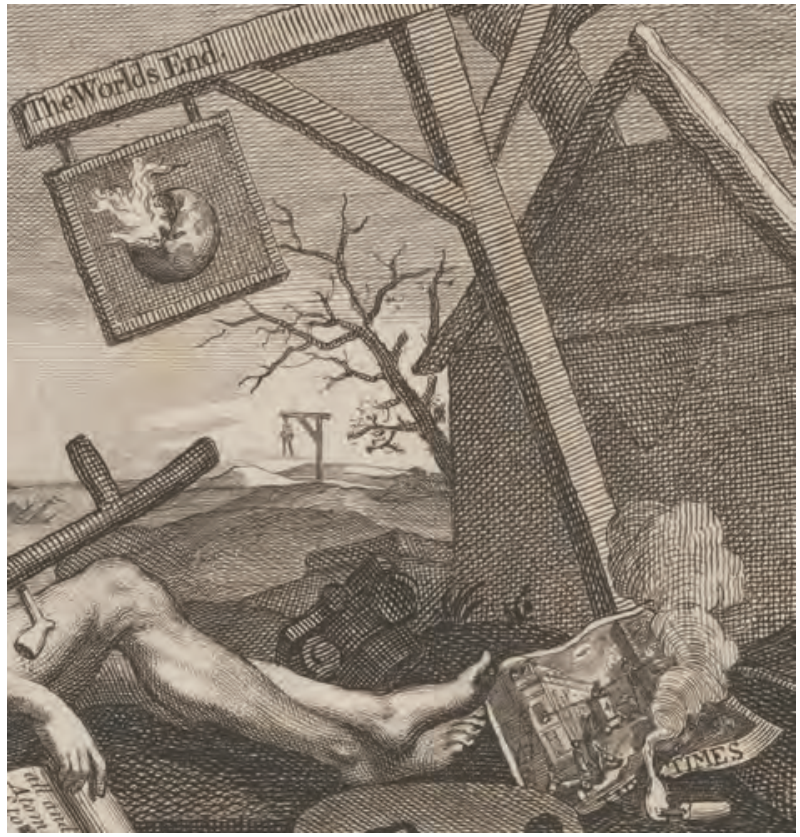

Fig. 3 William Hogarth, Tail Piece, or The Bathos, March 3, 1764, detail Metropolitan Museum of Art (Public Domain) 
The print that Ireland identifies as being ignited by 'an inch of candle' is The Times (the title of which is legible, Fig. 3), which Hogarth produced two years before The Bathos, in $1762^{18}$ (Fig. 4).

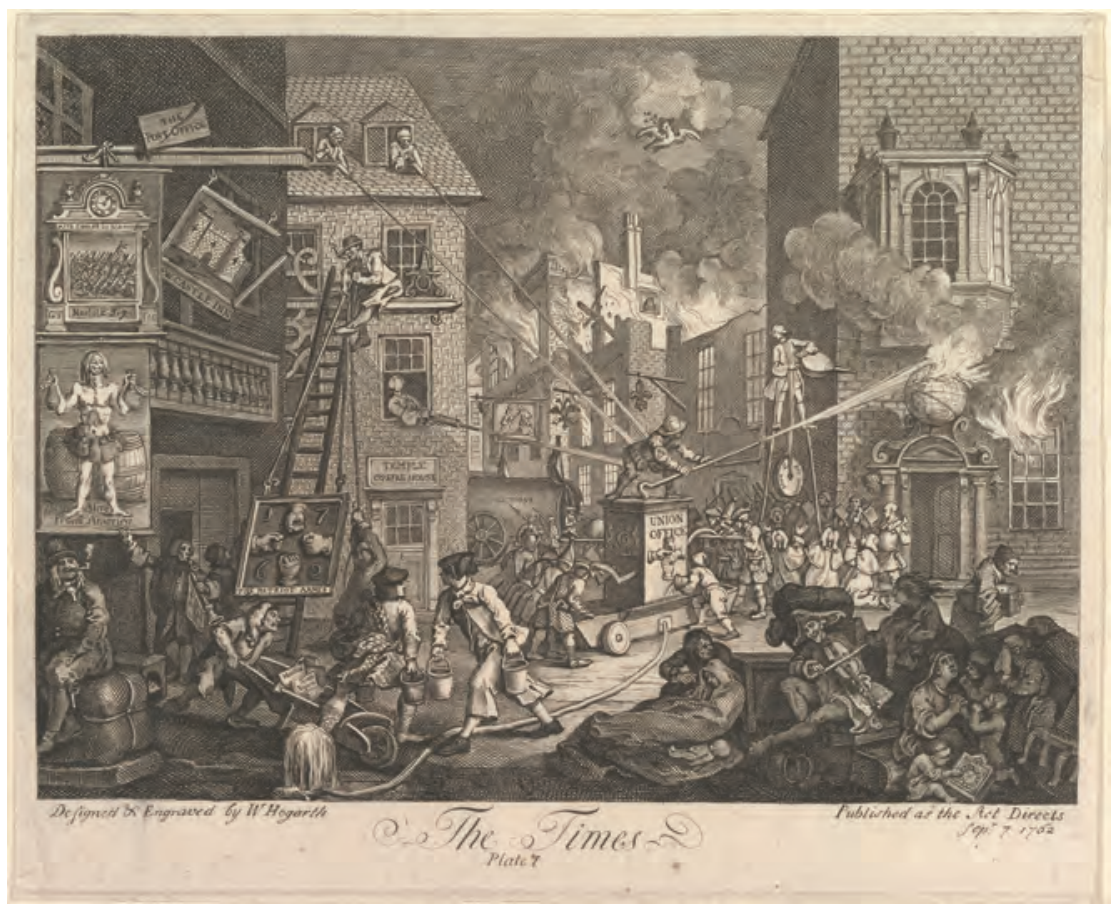

Fig. 4 William Hogarth, The Times Plate 1, 1762

Metropolitan Museum of Art (Public Domain)

According to the detailed analysis of The Times provided by Ireland, ' $[\mathrm{t}]$ he first object is a quarter of the globe on fire, supposed to be Europe; and France, Germany, and Spain, denoted by their respective arms, ${ }^{19}$ are represented in flames, which appear to be extending to Great Britain

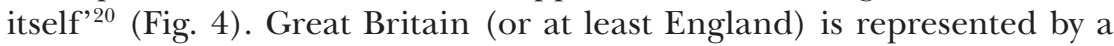
building on the right, where the globe hangs as the sign above the front door. This house features a distinctive overhanging bay window on the first floor, similar to the one at Hogarth's house in Chiswick-and thus positions the artist, at least by proxy, within the picture and at the sign of the world's end ${ }^{21}$ (Fig. 5). 


\section{Ireland continues,}

And this desolation is continued and increased by Mr. P- [Pitt] [...] with a pair of bellows blowing up those flames which others are endeavouring to extinguish. He is mounted on the stilts of the populace [...] [while] a wheelbarrow, overladen with Monitors and North Britons, [is] brought in, to keep up the flame. The respectable body depictured under Mr. $\mathrm{P}-$, are the $\mathrm{m}$ - [magistrates] of London, who are worshipping the idol they had formerly set up: whilst a German prince, who alone is sure to gain by the war, is amusing himself with a violin among his miserable countrymen ${ }^{22}$

- that is, a group of suffering refugees who have taken the brunt of the war, directly visible from Hogarth's window/viewpoint (lower right, Fig. 4).

\section{THE TIMES, JOHN WILKES AND 'ABUSE OF THIS WONDERFUL PAINTER'}

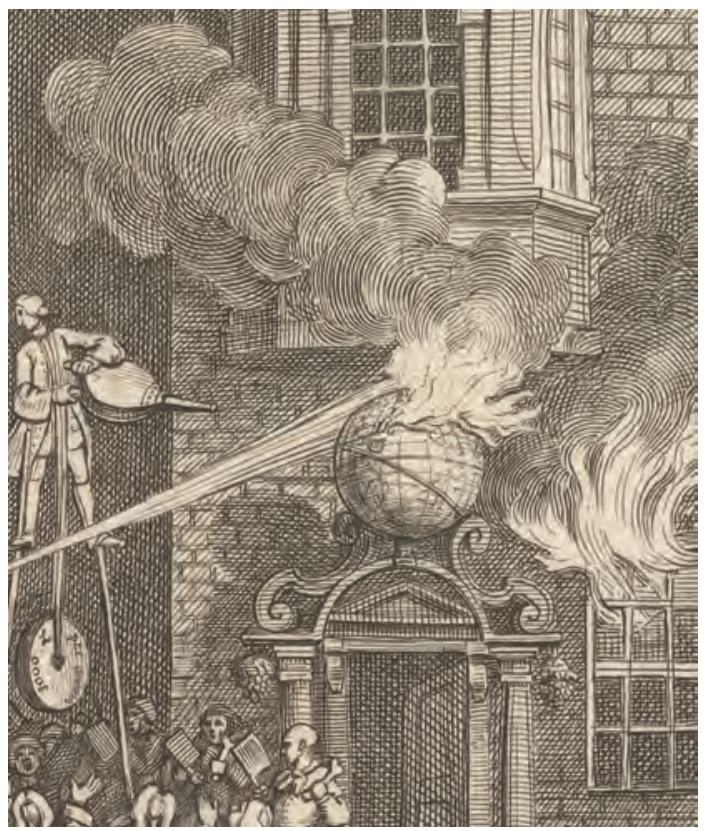

Fig. 5 William Hogarth, The Times Plate 1, 1762, detail Metropolitan Museum of Art (Public Domain) 
In The Times, William Pitt (1708-1778), who was at the time Secretary of State, directs his bellows towards a globe that is bursting into flames (Fig. 5). This image of the globe on fire bears a striking resemblance to the one depicted on the tottering World's End tavern sign in The Bathos (Fig. 3), at the base of which The Times is taking fire, like a piece of smouldering kindling that may soon burst into flames.

The Times became the subject of considerable controversy, and set off a series of acrimonious public exchanges. Hogarth recalled that his 'subject which tended to the restoration of peace and unanimity' nonetheless 'gave great offence to those who were trying to foment destruction in the minds of the populace', at a time 'when war abroad and contention at home engrossed every one's mind'. ${ }^{23}$ Bindman explains that 'the artist's open declaration of his support for Bute' (First Lord of the Treasury, or Prime Minister, John Stuart, Third Earl of Bute [1713-1792]) and his attempts at negotiating peace in Europe (which would impact negatively on merchant interests in the City, associated with acquisition of colonial territories, which prospered during the war) 'brought a quietly devastating response' from Pitt's supporter-described by Hogarth in his autobiographical notes as 'till now rather my friend and flatterer' - the libertarian John Wilkes (1725-1797). ${ }^{24}$

Wilkes launched a stinging response to The Times in his paper The North Briton-a barrow-load of which is shown being wheeled in to fuel the flames in the print (lower left, Fig. 4). The language of the attack, which included scathing personal criticism of Hogarth and his talent as an artist, as well as his politics, resonates with terms synonymous with bathos in its meaning of 'depth', lowest phase' and 'descent'.

Wilkes professed to be

grieved to see the genius of Hogarth [...] sunk to a level with the miserable tribe of (political J.W.) party-etchers; and now, in his rapid decline entering into the poor politicks of the faction of the day, and descending to low [my emphasis] personal abuse, instead of instructing the world, as he could once, by manly moral satire. ${ }^{25}$

Acknowledging that Hogarth had 'the rare talent of gibbetting' (that is, holding others up to derision) 'in colours, and that in most of his works, he has been a very good moral satirist', Wilkes went on to savage the artist's 'historical or portrait pieces', contending that they 'are now considered almost beneath all criticism' ${ }^{26}$ Commenting more generally on Hogarth's powers as an artist he added, 'I have observed some time his setting sun. He has long been very dim, and almost shorn of his beams'. ${ }^{27}$

Musing whether this perceived decline may be put down to "the frowardness (contrariness J.W.) of old age', Wilkes continued, 'Gain and 
vanity have steered his little light bark quite through life. He has never been consistent but with respect to those two principles'. ${ }^{28}$

\section{THE ANALYSIS OF BEAUTY, THE LINE OF BOOTY AND PAUL SANDBY'S NEW DUNCIAD}

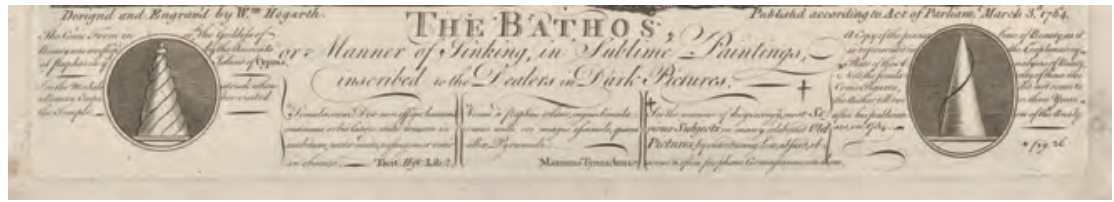

Fig. 6 William Hogarth, Tail Piece, or The Bathos, March 3, 1764, detail Metropolitan Museum of Art (Public Domain)

As well as making allusion to Peri Bathous and The Times, references to Hogarth's earlier works, including his treatise The Analysis of Beauty (1753) and the print Time Smoking a Picture (1761), may be found in The Bathos. Most obvious of these is a pair of cones with serpentine lines entwining them, on either side of the title below the composition, representing the 'conic form in w $w^{\text {ch }}$ the Goddess of Beauty was worship d by the Ancients' and 'a Copy of the precious Line of Beauty' as it appeared in the Analysis of Beauty (Fig. 6).

In The Analysis of Beauty-a discourse on 'fluctuating ideas of TASTE'29 published eleven years before The Bathos-Hogarth identifies the 'line of beauty' (depicted on his palette in his self-portrait of 1745 https://www.tate. org.uk/art/artworks/hogarth-the-painter-and-his-pug-n00112) in a 'serpentine' line, which he discovers in the intricate forms of nature and in graceful human movement. ${ }^{30} \mathrm{He}$ also makes outspoken pronouncements on prevailing notions of the sublime, and offers a range of practical and theoretical recommendations concerning artistic practice, emphasizing the importance of working from observation. According to Bindman, The Analysis 'can be seen as Hogarth's attempt [...] to establish himself as an artist of substance, able to justify his practice on lofty terms', and as his 'reaction against the classicizing aesthetic of the Connoisseurs, basing its own aesthetic on empirical observation rather than the authority of the past'. ${ }^{31}$

The Analysis of Beauty was generally well received, especially in Europe, but it also brought detractors. Amongst these, the artist Paul Sandby (1731-1809) launched 'a sustained campaign against Hogarth' ${ }^{32}$ in a series of satirical etchings published during 1753 to 1754 in response to The Analysis. Advertised as 'The Analysis of Deformity [...] or, a new Dunciad [...] done with a View to fluctuate the fix'd Ideas of Taste', ${ }^{33}$ Sandby's title 
referred derisively to The Analysis of Beauty, and also to Pope's mock-heroic poem The Dunciad (produced between 1728 and 1743) in which the poet disparaged the triumph of dullness and mediocrity in Georgian culture.

The 'set of engravings, entitled, the New Dunciad' tops a list of 24 'PRINTS PUBLISHED TO RIDICULE THE Analysis, Times, etc.', in Ireland's Hogarth Illustrated. Other works on this list include titles such as 'The Author sinking under the weight of his Analysis', and 'The Analyst [...] in his own Tastedescribed by Ireland as 'a vile, nauseous and vulgar print'-as well as 'The BUTIFYER. A Touch upon The Times Plate I', in which Sandby returned to mocking the Line of Beauty, in 1762. ${ }^{34}$ A satire (like Wilkes's attack in the North Briton) on Hogarth's support for Bute in The Times, he is depicted 'in the character of a shoe-black', on a platform at the top of a ladder in the act of 'blackening a great jack boot', which bears the inscription Line of Booty. The serpentine Line of Beauty is present on the upper side of Hogarth's palette which hangs from the ladder, at the top of which a bucket bears the label 'PENSION'. ${ }^{35}$ (https://research.britishmuseum.org/research/collection_online/collection_object_details.aspx?objectId=1478456\&partId=1).

\section{TIME SMOKING}

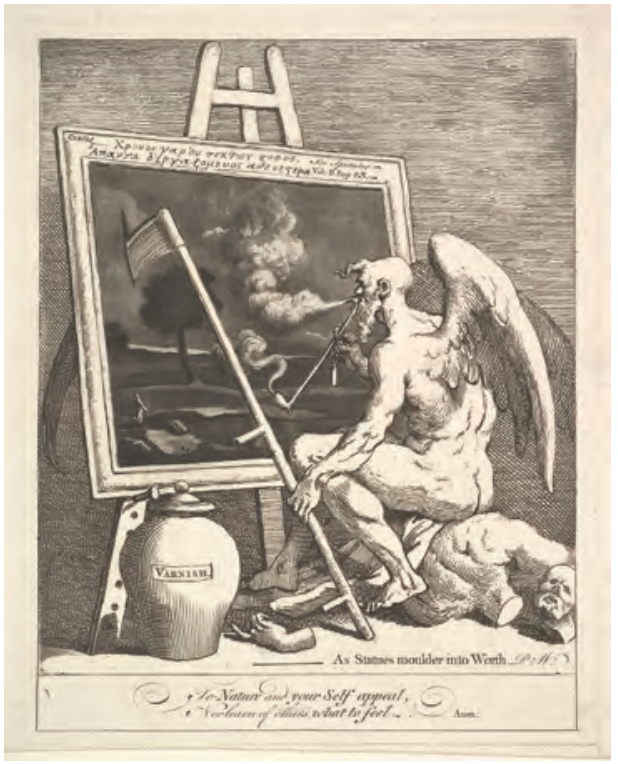

Fig. 7 William Hogarth, Time Smoking a Picture, c. 1761

Metropolitan Museum of Art (Public Domain) 
The figure of Time and reference to 'dealers in dark pictures', in the subtitle of The Bathos, also bring together elements in common with Hogarth's earlier print Time Smoking a Picture (1761) (Fig. 7), in which Time takes the artist's place at his easel in order to darken the varnish on a landscape painting with the smoke from his pipe. This work would have been familiar to Hogarth's contemporaries as one of his 'Satires on "Connoisseurs", whose taste for imported Dutch Old Masters, and modern works that emulated them with the use of darkened varnish, ran counter to the artist's commitment to chronicling contemporary life, his longheld (though unrealised) ambition to establish an independent school of English painting, and the theoretical basis of The Analysis of Beauty. ${ }^{36}$

In both The Bathos and Time Smoking a Picture, Time is depicted as a winged and naked bearded old man, with a distinctive forelock, holding a scythe. In The Bathos, the blade of Time's scythe (Fig. 8) appears to be broken off at the same point at which it is buried in the landscape painting in Time Smoking a Picture (Fig. 7) —where it is 'driven through [...] to give proof of its antiquity, —not only by sober, sombre tints, but by an injured canvas'. ${ }^{37}$ The exhalation with which Time had darkened the colours in the painting to a fashionably antique hue in Time Smoking appears as his final breath in The Bathos. Spiralling upwards, the puff of smoke carries the word FINIS into the darkening sky to meet the cloud on which Apollo's chariot, with its driver and horses apparently all dead, is 'sink[ing] into endless night.' ${ }^{38}$

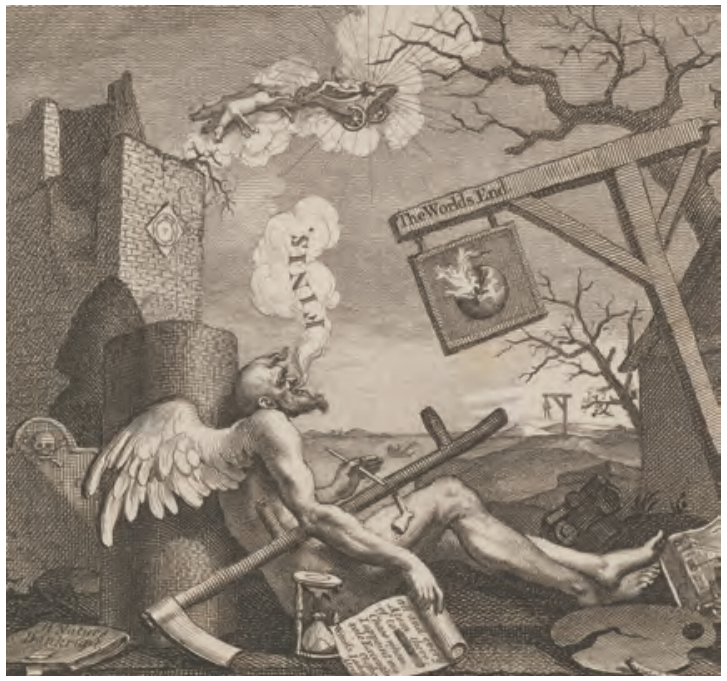

Fig. 8 William Hogarth, Tail Piece, or The Bathos, March 3, 1764, detail Metropolitan Museum of Art (Public Domain) 


\section{'MR. HOGARTH IS SAID TO BE DYING, AND OF A BROKEN HEART'}

Ireland makes a close reading and comparison of Peri Bathous and The Bathos, and gives a detailed commentary on Wilkes's response to The Times in the North Briton. He notes that Wilkes's 'attack' opened 'with a ridicule of the Analysis of Beauty' ${ }^{\prime 3}$ and, reading Wilkes's criticism in full, it becomes possible to see Time in The Bathos not only as Chronos (the classical Greek personification of time) but also as the artist, with his serpentine Line of Beauty appearing as a rupture that fractures the palette by his side (lower right, Fig. 8). Nichols describes how 'at the time these hostilities' concerning The Times 'were carrying on [...] [Hogarth] was visibly declining in his health', ${ }^{40}$ and the artist himself describes '[b]eing at the time very weak, and in a kind of slow fever' - adding that the attack from '[o]ne of the most notorious' among his detractors (his sometime friend Wilkes) 'in so infamous and malign a style [...] could not but seize a feeling mind'. ${ }^{41}$

The depiction of the afflicted Apollo with abbreviated rays of light surrounding his stricken chariot (centre top, Fig. 8) may then point to Wilkes's verdict on Hogarth's declining powers as an artist: 'I have observed some time his setting sun. He has long been very dim, and almost shorn of his beams'. ${ }^{42}$ At the centre of the composition, next to Time's left hand, the ship that founders beneath Apollo's falling chariot may, in turn, be read as a response to Wilkes's devastating remark that ' $[g]$ ain and vanity have steered his little light bark quite through life', as well as to the subtitle of The Bathos, with its overall theme explicitly linking it to Peri Bathous: The Art of Sinking in Poetry-Manner of Sinking, in Sublime Paintings. ${ }^{43}$ The gibbet with the remains of a man hanging from it (on the right beneath the inn sign, Fig. 8) may be understood as a reference not only to Wilkes's acknowledgement of Hogarth's 'rare talent of gibbetting', but also to his judgement on-and assassination of - the character of his former friend. ${ }^{44}$

Continuing the gallows humour, the inn sign that hangs scaffoldlike over the dying figure of Time may point to Hogarth's involvement in, and criticism attracted by, the Exhibition of Sign-Painters in 1762. A burlesque on the annual exhibition of the Society for the Encouragement of Arts (of which Hogarth had been a member, before falling out with them in 1757), ${ }^{45}$ the Sign-Painters' show was mounted to coincide with the Society's exhibition, and designed to ridicule both the artists it represented and the connoisseurs who patronised them. It inevitably angered the artists and caused 'a perfect storm among the newspapers'46 — not least for charging the public to view a display of 
(actual) street signs depicting subjects that were as hackneyed as they were satirical. ${ }^{47}$

Combining comparisons with Peri Bathous and the North Briton, the 'principal character' of The Bathos emerges not only as the allegorical figure of Time (a trope recommended in Peri Bathous), but also as a metaphor for the once 'illustrious ${ }^{48}$ chronicler of contemporary times, Hogarth himself. The image of the formerly great artist 'taken up in mean and trivial matters', ${ }^{49}$ is delineated with the metaphors of sinking, descending and declining so vividly evoked by Wilkes-who informed Richard Grenville-Temple, in a letter written two months after he published his attack in the North Briton, that 'Mr. Hogarth is said to be dying, and of a broken heart'..$^{50}$

\section{THE OBJECTS OF THE END OF TIME}

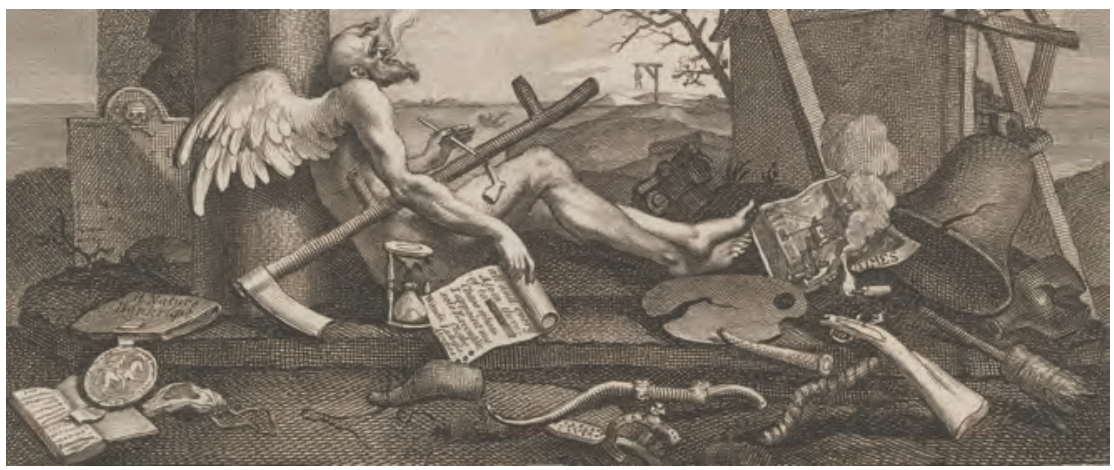

Fig. 9 William Hogarth, Tail Piece, or The Bathos, March 3, 1764, detail Metropolitan Museum of Art (Public Domain)

Hogarth was certainly injured by the censure of his work. Reflecting on 'the chief things that have brought much obliquy on me', he cited both The Analysis of Beauty and The Times, and complained of being '[p] estered with caricature drawings, and hung up in effigy in prints; accused of vanity, ignorance and envy'. He added that, 'to say that such malicious attacks did not discompose me, would be untrue'. ${ }^{51}$

Wilkes's indictment that

the darling passion of Mr. Hogarth is to shew the faulty and dark side of every object. He never gives us in perfection the fair face of nature, but admirably well holds out her deformities to ridicule, ${ }^{52}$ 
seems to have met its mark. In The Bathos Time/Hogarth is besieged by a battalion of broken objects presented in the style of a still life-'a species of painting' that he felt should 'be held in the lowest estimation'. ${ }^{53}$

The image of a man surrounded by broken household items would have been familiar to Hogarth and his contemporaries, as the 'stock joke' figure of 'Nobody' popularized in satirical broadsides. Originally characterized as someone who was "commonly blamed for what everybody did' when things got broken, but took no responsibility for the damage, Nobody was also known as 'the type of man that was put upon', and one who might be 'opposed [...] to the pretentious Somebody'. ${ }^{54}$ In the catalogue accompanying the Sign Painters' Exhibition, for instance, 'NOBODY, alias SOMEBODY. A Character', and 'SOMEBODY, alias Nobody. A Caricature. Its Companion. Both these by Hagarty' (a thinly disguised pseudonym for Hogarth), are listed immediately before 'The WORLD'S END'. ${ }^{55}$

In his comprehensive commentary on the objects of 'the end of time ${ }^{56}$ depicted in The Bathos, Ireland notes that Hogarth 'gleaned' many of his images 'from the common field of the poor company of punsters'-and the use of visual wordplay in his final print has much in common with the humour of the Sign-Painters' catalogue. A 'COBLER'S [sic] END' (a length-or line?-of thread) (beneath the broken hourglass, Fig. 9) 'twisted round a WOODEN LAST ${ }^{57}$ - the form on which the cobbler crafts a shoe, or boot-play punningly on notions of termination. They may also refer to Sandby's combined punning on Hogarth's political support for Bute and his competitor's theoretical work, the 'Line of Booty'. The cobbler's last closely resembles the profile of the boot in Sandby's The Butifyer, and other objects in The Bathos are combined in a series of contrasts which may in turn allude to his New Dunciad.

In Pope's original Dunciad (evoked by Sandby to ridicule Hogarth's Analysis of Beauty), the Goddess Dulness rises 'To blot out Order, and extinguish Light, /Of dull and venal a new World to mold', ${ }^{58}$ in which

[...] motley Images her fancy strike,

Figures ill pair'd, and Similes unlike.

She sees a Mob of Metaphors advance,

Pleased with the madness of the mazy dance:

How Tragedy and Comedy embrace;

How Farce and Epic get a jumbled race;

How Time himself stands still at her command..$^{59}$

On the lower right of The Bathos, surrounding the stilled and dying figure of Time (Fig. 9), Hogarth's 'Mob of Metaphors' combine 'the huge cracked' and clapper-less (or silenced) 'bell of the cathedral', traditionally 
rung in celebration of victory when the country was at war ${ }^{60}$ and to summon the faithful to church (also 'for persons about to expire, to advertise the people to pray for them', and to chime the passing hours) ${ }^{61}$ with 'the broken bottle of the tavern'. ${ }^{62}$ A number of broken weapons- the butt of a musket, the handle of the whip of satire, and a snapped bow-are grouped around a splintered artist's palette (the fracture in which echoes that in the bell) ${ }^{63} \mathrm{~A}$ 'worn out brush' included in this group, closely resembling the one that appears as an attribute of Hogarth in A Sett of Blocks for Hogarth's Wigs (1762) —an attack on Bute depicting a boot as his emblem together with the inevitable reference to Hogarth's 'Lines of Buty'-is 'contrasted [...] with the broken crown'64 (https://www.britishmuseum. org/research/collection_online/collection_object_details/collection_ image_gallery.aspx?assetId=371796001\&objectId=3082257\& partId $=1$ ).

\section{THE BROKEN CROWN}

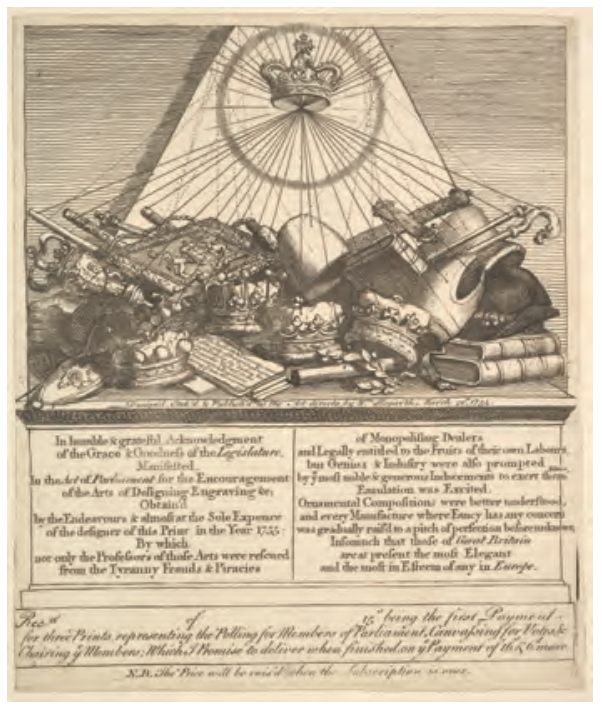

Fig. 10 William Hogarth, Crowns, Mitres, Maces \&c., 1755

Metropolitan Museum of Art (Public Domain)

In the centre of the lower edge of The Bathos a broken crown slips out of the picture (Fig. 9), and may be compared with the 'Royal Crown [...] darting its rays on mitres, coronets and the Chancellor's great seal, the Speaker's hat, \&cc., \&c.', at the apex of Hogarth's design for a subscription 
ticket for four of the Election prints produced during the 1750s, entitled Crowns, Mitres, Maces $\mathcal{E}^{2} .^{65}$ (Fig. 10).

In the earlier print these emblems allude to the artist's successful lobbying for the introduction of legislation known as 'Hogarth's Act' (1735), which provided copyright protection for artists against 'the Tyranny, Frauds, and Piracies of Monopolizing Dealers' in their work. ${ }^{66}$ In The Bathos, produced almost thirty years after that success, and two years after Wilkes's scathing comment that he had 'observed some time his setting sun. He has long been very dim, and almost shorn of his beams' ${ }^{67}$ rays of light are truncated and emanate not from crowning achievements, but from Apollo's doomed chariot (Fig. 8). Meanwhile, Time's last breath spirals upwards echoing the configuration of the cloud of smoke from the candle stub that sets light to the crumpled copy of The Times (Fig. 3).

\section{EXEUNT OMNES AND THE END OF ALL THINGS}

In his right hand, Time holds his Will (Fig. 9) in which (according to Ireland) 'the great globe itself, and all which it inherits, is bequeathed to CHAOS,- - appointed sole executor: and this his last act, is witnessed' and sealed by the Three Fates: Clotho (who spins the thread of life), Lachesis (who measures the thread) and Atropos (who cuts it). ${ }^{68}$ Wheezing his final breath, Time/Hogarth leans against a broken column-which may, perhaps, be interpreted as a plinth from which he has tumbled.

Behind him a simple headstone decorated with a skull and crossbones awaits; in the foreground a worn and empty purse with a hole in it lies on the ground beside 'a commission of bankruptcy [...] issued and awarded against [H.] NATURE', bearing the Seal of the Realm ${ }^{69}$ - suggestive of the artist's admission that, although his friends counselled him to 'laugh at the nonsense of party-writing' from his critics, he nonetheless felt unable to 'rest myself', because

\footnotetext{
"Who steals my gold, steals trash; 'tis something; nothing; [...]

But he that filches from me my good name,

Robs me of that which not enriches him,

And makes me poor indeed." ${ }^{70}$
}

Finally, according to Ireland, 'THE BOOK OF NATURE, in which [...] [the artist] was so deeply read, and from whence he drew all his images, is open at the last page $[\ldots]$ and with the words engraven on the last leaf of that volume which he so well studied', the stage direction 'EXEUNT OMNES' (all leave). ${ }^{71}$ 
Overall, the effect of this accumulation of objects and references assembled around the ailing figure of Time beneath the dying sun, at the sign of the World's End, is reminiscent of the last lines of the final book of Pope's Dunciad, in which triumphant Dulness, 'Daughter of Chaos and eternal Night', ${ }^{72}$ brings proceedings to an end:

Lo! Thy dread Empire, CHAOS! is restor'd;

Light dies before thy uncreating word:

Thy hand, great Anarch! lets the curtain fall;

And Universal Darkness buries All. ${ }^{73}$

\section{A POINT-BY-POINT REJOINDER TO HIS CRITICS}

Linking Peri Bathous with The Bathos-mixing tragedy and comedy, farce and epic-Hogarth exploits the emblems of vanitas painting while undermining the Old Master genre to which they belong. ${ }^{74}$ Combining nature morte (the still-life composition of broken objects) and tableau vivant (the figure of dying Time), he pokes fun with references to the satirical Peri Bathos while also pointing sardonically to the wounding and very public criticisms he had received. Through a close reading of Wilkes's scathing attack that followed publication of The Times, and Sandby's references to Pope's Dunciad in his satires on Hogarth's works and political support for Bute, we see that the figure of Time in The Bathos may also be read as a representation of the artist himself: the put-upon Nobody besieged by wreckage for which he does not believe himself responsible.

Produced during the final months of his life, The Bathos emerges as a detailed point-by-point rejoinder in which the injured and dying artist nonetheless rallies in opposition to 'the pretentious Somebody': his critics. ${ }^{75}$ Assembling a range of broken weapons and 'a mob of metaphors', ${ }^{76}$ including those of sinking, decline and 'low ideas', ${ }^{77}$ around the inflammatory print of The Times (which threatens to set fire to the signboard hanging over him like a gallows) Hogarth focuses on specific emblems - the 'setting sun' of his powers as an artist, the 'little [...] bark' of 'gain and vanity', ${ }^{78}$ the gibbet, the oft-repeated 'line of Booty' and references to the Dunciad, so publicly aimed at him by two of his principal detractors.

\section{AFTERWORD: AFTERLIFE AND SITUATION OF GRAVES}

In our own time, Paulson offers a further perspective, arguing that in The Bathos- 'the culmination of such pessimistic images'-Hogarth takes 
'his general composition, the configuration of objects, and some of the particular items, from [Albrecht] Dürer's [1471-1528] engraving, Menlancholia [sic] [1514]'. ${ }^{79}$ He further proposes that a very likely 'primary inspiration' for Hogarth would have been '[Louis François] Roubiliac's [1702-1762] Hargrave Monument (Westminster Abbey, 1757) with crumbling figures and Time [...] breaking his scythe across his knee'. ${ }^{80}$ Bindman takes up Paulson's theme, arguing that Hogarth 'takes many images familiar from the elaborate figural tombs of his contemporaries like [...] Roubiliac and strips them of all intimations of the afterlife' ${ }^{81}$ (http:// www.artandarchitecture.org.uk/images/full/585e2e2e69d8d42e9a99ea 9b0664e63138112759.html).

Bindman adds that

All the elements emblematic of monuments, of enduring fame or of earthly life beyond death-palette, crown and weapons-are broken [...] It is perhaps the bleakest image of extinction in the whole of eighteenth-century art [...] Hogarth refuses to offer what all devotional poems, meditations and tombs of the time offered to the viewer: the construction of a life beyond death, either in the world beyond or in the memory of posterity. ${ }^{82}$

Nonetheless, as Paulson argues, Hogarth's prints were 'always his one source of appeal beyond his "enemies" [...] his final plea to posterity [...] a projection of himself into that dark world beyond his present sickness and discontent'. ${ }^{83}$ From our vantage-point in that future we may see that his deeply pessimistic view of life, produced in the months before his own would come to an end, is in marked contrast with the 'relentless' and positive 'biographical coverage', and the frenzied collecting of his work, that followed his death ${ }^{84}$-after which he remained (and still remains) crowned for his artistic achievements in 'the memory of posterity'. ${ }^{85}$

\section{HOGARTH'S HONOUR'D DUST LIES HERE}

Hogarth's reputation as a successful painter and his dedication to the portrayal of Nature (both savaged by Wilkes) and The Analysis of Beauty (disparaged by Sandby) are celebrated and emblemised on his tomb-'a plain but neat pyramidical monument ${ }^{\prime \prime 6}$ erected near his former home, in the churchyard of St Nicholas in Chiswick. The inscription, written by his friend the actor David Garrick with advice from Samuel Johnson, ${ }^{87}$ addresses the reader directly, and acknowledges the potential moment of communication with the dead which may occur in the places where their 'honour'd dust' is laid: 
Farewell, great painter of mankind,

Who reach'd the noblest point of art;

Whose pictur'd morals charm the mind,

And through the eye correct the heart.

If genius fire thee, reader, stay;

If Nature touch thee, drop a tear:

If neither move thee, turn away,

For Hogarth's honour'd dust lies here. ${ }^{88}$

In addition to Garrick's words, Hogarth's tomb is embellished with objects symbolic of his success (Fig. 11): a laurel-wreath (the classical attribute of 'glory, power and eternity') ${ }^{89}$ hanging from a mahlstick (the implement used by painters to support their hand as they work), a palette and brushes (the handles of which are visible), an open book ('Analysis of Beauty', the lettering weathered but still legible), a mask (with an expression that is neither tragic nor comic but somewhere in between), a scroll of paper (a reference perhaps to the Letters Patent appointing him Sargeant-Painter to the King in $1757,{ }^{90}$ or to Hogarth's Act of 1735), and a sprouting oak leaf. These emblems of 'enduring fame' - which have survived throughout more than two hundred and fifty years of Hogarth's afterlife-are in striking contrast with the wreckage, ruined buildings and blasted and leafless trees that make up the desolate landscape of the artist's final print. ${ }^{91}$

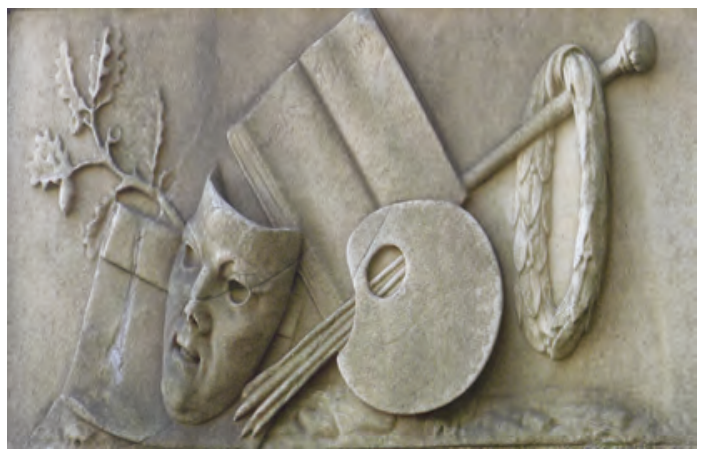

Fig. 11 Emblems on William Hogarth's tomb, 1771

St Nicholas churchyard, Chiswick

(C) Jane Wildgoose, The Wildgoose Memorial Library

At the height of Hogarthomania at the end of the eighteenth and the beginning of the nineteenth centuries, Hogarth's grave was sufficiently well-known as a landmark for a number of prints of it to be produced, 
including a View from Hogarth's Tomb, Chiswick (1823) —'a memento of a visit to the family monument ${ }^{\prime}{ }^{2}$ - depicting a romantic scene set among leafy trees overlooking the River Thames, with a distant view of St. Paul's Cathedral on the horizon ${ }^{93}$ (Fig. 12).

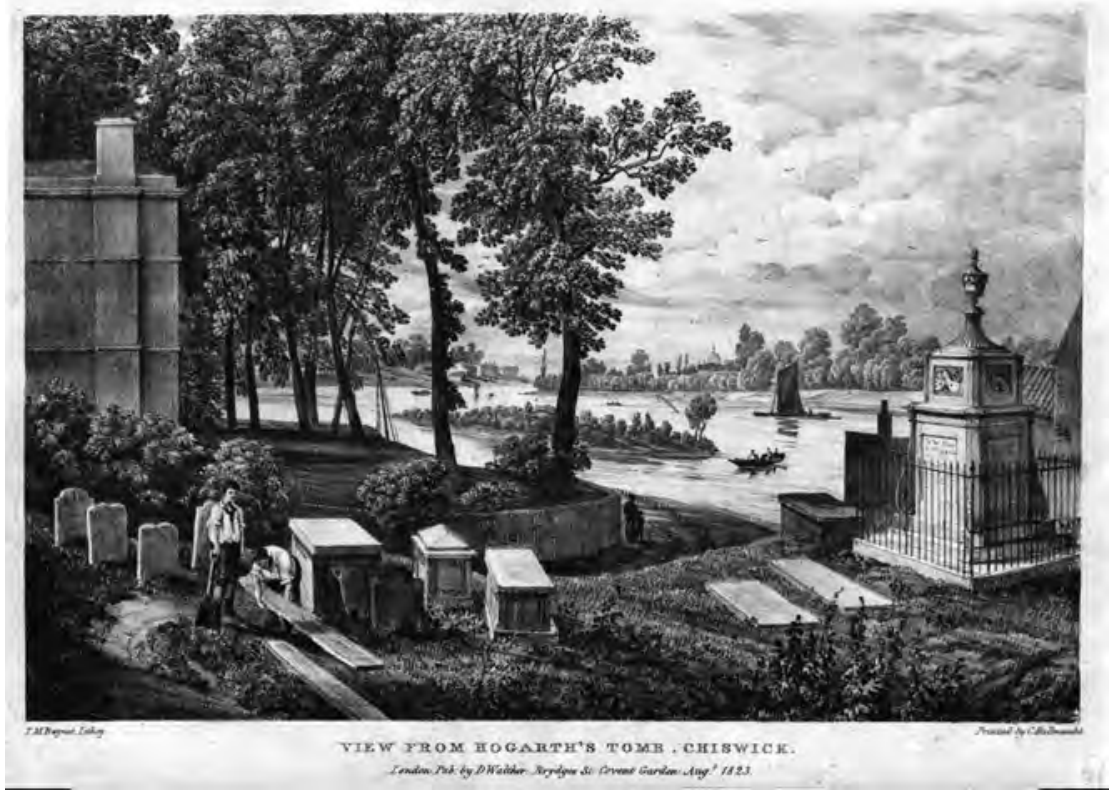

Fig. 12 T. M. Baynes, lithog., View from Hogarth's Tomb, Chiswick, 1823 (C) Hounslow Local Studies Collection, Chiswick Library

According to Edward Walford, writing half a century later, the churchyard was distinguished by holding 'the ashes of more than a fair sprinkling of those whose names have been inscribed on the roll of the Muses, or have achieved or inherited names illustrious in history'. However, it was Hogarth's 'large and conspicuous monument' rather than that of any of the local worthies-or indeed his nearby house-that was singled out to appear as the central motif around which the landmarks of the church and manor house revolve, in a view illustrating Chiswick by William Henry Prior (1812-1882) in Walford's London Old and New (1878) ${ }^{94}$ (Fig. 13).

Although Hogarth's tomb appears as central to the history and topography of Chiswick in 1878, his nearby house (his second home-a 'country refuge [...] weekend and summer' residence for the last fifteen years 


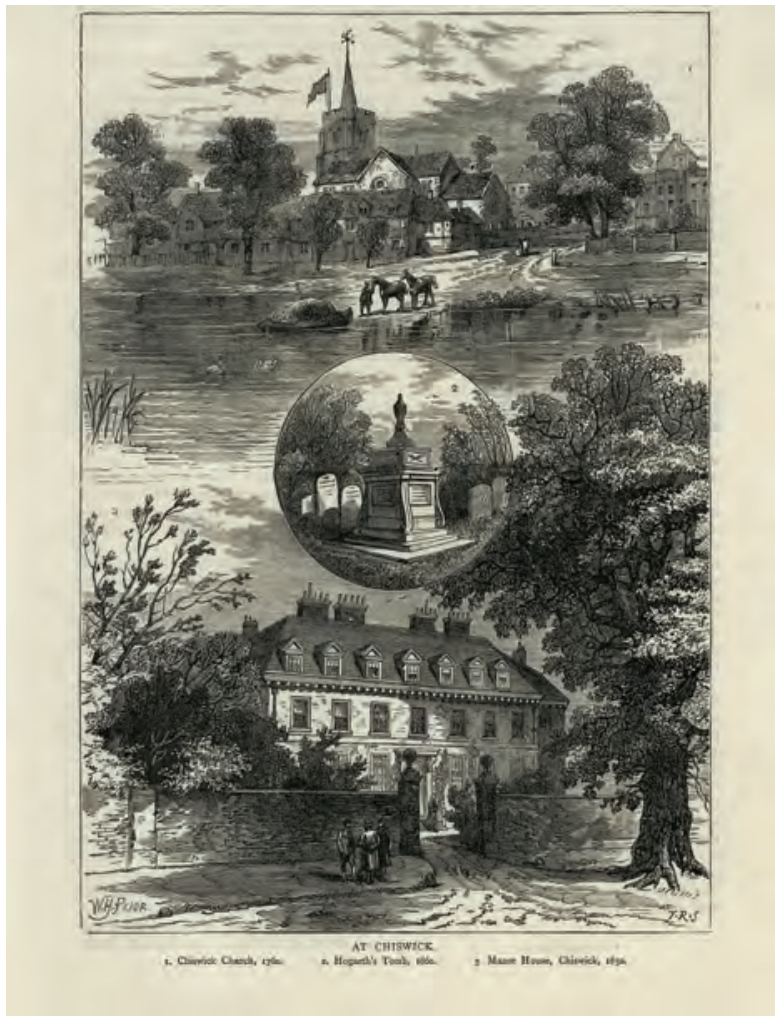

Fig. 13 William Henry Prior (1812-1882), At Chiswick:

1 Chiswick Church, 1760; 2 Hogarth's tomb, 1860

3 Manor house, Chiswick, 1850

Edward Walford, Old and New London, 1878

(C) Jane Wildgoose, The Wildgoose Memorial Library

of his life $)^{95}$ was threatened with demolition 'to make way for "the construction of villa residencies"', in 1901. ${ }^{96}$ It was, however, purchased by a local landowner who opened it to visitors, and remains on view to the public under the ownership and management of the London Borough of Hounslow supported by the Hogarth Trust.

The house stands on what has long been known as Hogarth Lane; the Hogarth Roundabout (one of the capital's busiest and noisiest road junctions) is nearby, and some half dozen streets in the area are named after the artist, whose statue by Jim Mathieson (2001) stands on Chiswick High Road. On a visit to the house as part of research for this article, I went 
to see the tomb, which was immediately recognizable from eighteenthand nineteenth-century prints, with the addition of an information panel providing a brief biography and transcriptions of the now weatherworn inscriptions (Fig. 14). At the base of the monument fading bunches of flowers indicated that Hogarth's grave continues to function as a place of pilgrimage today.

From Chiswick, I made my way to Leicester Square: where Hogarth lived for over thirty years from 1733; where 'most of his finest works were engraved and sold', where the artist died in 1764, and where his widow continued to live and sell prints until her death in $1789 .{ }^{97}$ But I could find no trace of the artist there. The house, at 'the sign of "the Golden Head", was demolished in $1870 ; 9^{98}$ a bust (1875) by Joseph Durham (1814-1877) had stood in the Square until 2012 but was removed as part of renovations when it was judged damaged beyond repair during cleaning in the 1990 s. ${ }^{99}$ None of the nearby roads bear Hogarth's name; there is no blue plaque, no biographical information.

Is it only coincidental, I wondered, that it is in Chiswick-where Hogarth's 'honour'd dust' still 'lies'-rather than in Leicester Square, that his life and his significance as a British artist and chronicler of his times are

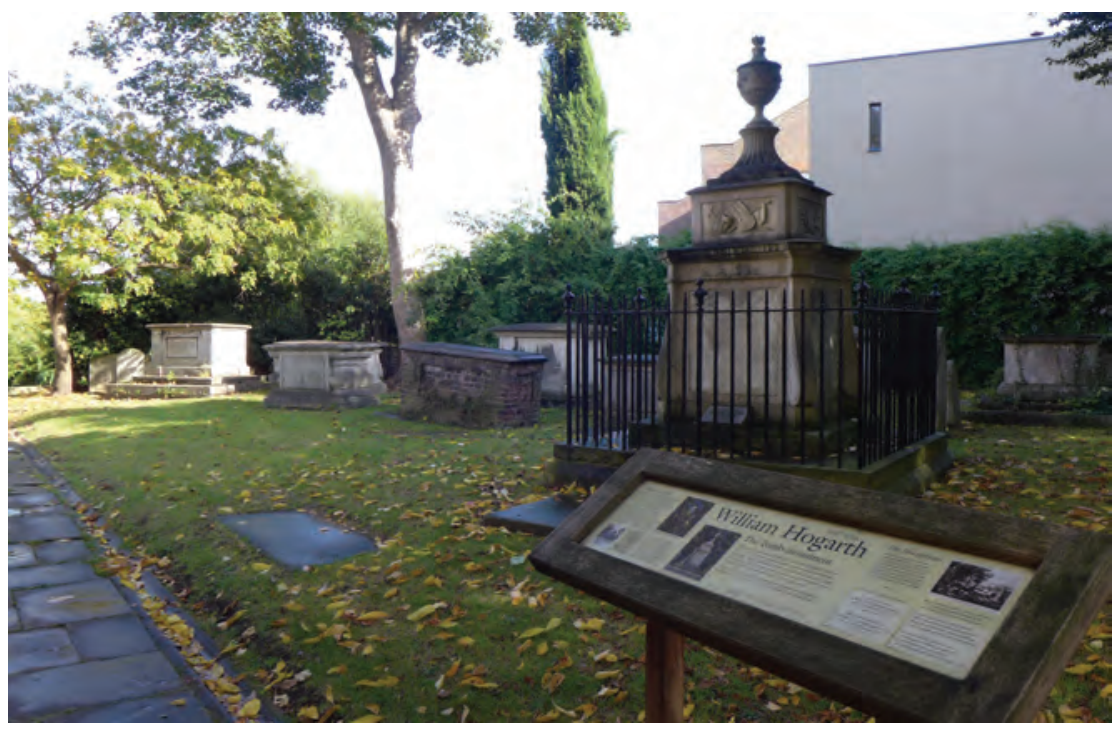

Fig. 14 William Hogarth's tomb with accompanying biographical information St Nicholas churchyard, Chiswick

(C) Jane Wildgoose, The Wildgoose Memorial Library 
remembered: in stone, on paper, in bronze, in bricks and mortar, and in street names? ${ }^{100}$ As Robert Pogue Harrison argues (citing a debt to Hogarth's contemporary, the Italian philosopher and historian Giambattista Vico [1668-1744]), '[1]ike human dwelling, the afterlife needs places to take place in. If humans dwell, the dead, as it were, indwell-and very often in the same space'. ${ }^{101}$

While Hogarth's prints continue to make their 'plea to posterity'102 in exhibitions in the real and virtual worlds, in monographs, and on display in his second home, his 'resting place' bearing its emblematic trophies of 'enduring fame'103 — the bright 'mirror' to the dark vanitas of his final work-remains unchanged: a locus (to paraphrase Harrison) where the artist's legacy may still be retrieved, and where his successful afterlife continues to be perpetuated. ${ }^{104}$

\section{WORKS CITED}

Allen, Brian. 'The Society of Arts and the First Exhibition of Contemporary Art in 1760.' RSA Journal (March 1991) 265-269.

Bedenk, Jochen. 'Myths of Nothingness. The End of the World and the Beginning ofAesthetic in Hogarth and Jean Paul.' In: Rüdiger Görner and Angus Nicholls (eds.), In the Embrace of the Swan: Anglo-German Mythologies in Literature, the Visual Arts and Cultural theory. Berlin \& New York: Walter de Gruyter, 2010, 187-210.

Bindman, David. Hogarth and His Times: Serious Comedy. Berkeley: University of California Press, 1997.

Brown, David. 'Statues effaced by acid clean.' The Guardian, 23 October 2002, https://www. theguardian.com/uk/2002/oct/23/localgovernment.arts.

Calmann, Gerta. 'The Picture of Nobody: An Iconographical Study.' Journal of the Warburg and Courtauld Institutes 23:1/2 (1960) 66-104.

Carruthers, Emilie. 'Origins of the Flower Crown.' 'The Iris: Behind the Scenes of the Getty.' Getty Institute, 4 May 2017, https://blogs.getty.edu/iris/the-ancient-origins-of-the-flower-crown/.

Conlin, Jonathan. "'At the Expense of the Public": The Sign Painters' Exhibition of 1762 and the Public Sphere.' Eighteenth-Century Studies 36:1 (2002) 1-21.

Cust, Lionel Henry. 'Ireland, John, (d. 1808).' Dictionary of National Biography (1892), https:// en.wikisource.org/wiki/Ireland,_John_(d.1808)_(DNB00).

Davis, Charles (ed.). 'William Hogarth: The Analysis of Beauty (London: Printed by John Reeves for the Author, 1753).' Fontes: Sources and Documents for the History of Art 1350-1750 52 (20 July 2010) 58, URL: https://archiv.ub.uni-heidelberg.de/artdok/1217/.

Donne, John. 'Diversions Upon Emergent Occasions.' In: Henry Alford (ed.), The Works of John Donne, D. D., Dean of Saint Paul's, 1621-1631. Vol. III. London: John W. Parker, 1839.

Eighteenthcenturylit. 'Seals.' http://eighteenthcenturylit.pbworks.com/w/page/102406330/ Seals.

Gunn, Ann V. 'The Fire of Faction Sources for Paul Sandby's Satires of 1762-1763.' Print Quarterly 24 (2017) 400-418.

Hamlett, Lydia. 'Longinus and the Baroque Sublime in Britain.' Tate, https://www.tate.org. uk/art/research-publications/the-sublime/lydia-hamlett-longinus-and-the-baroquesublime-in-britain-r1108498. 
Harrison, Robert Pogue. The Dominion of the Dead. Chicago: University of ChicagoPress, 2003. Hogarth Trust. https://williamhogarthtrust.org.uk/?page_id=705; https://williamhogarthtrust.org.uk/?page_id=107.

Hogarth, William. The Analysis of Beauty: A Reprint Including the Plates Formerly in Portfolio. Pittsfield: The Silver Lotus Shop, 1909.

Ireland, John. Hogarth Illustrated. Vol. I. London: J. \& J. Boydell, 1793.

Ireland, John. Hogarth Illustrated. Vol. II. London: J. N. Boydell \& Co., 1793.

Ireland, John. A Supplement to Hogarth Illustrated; Compiled from His Original Manuscripts, in The Possession of John Ireland, Author of the Two Volumes Published by Messrs. Boydell. London: Published for the author by G. \& W. Nicol and Messrs. Boydell, 1804.

Ireland, John. Hogarth Illustrated from His Own Manuscripts. Vol. III. London: Boydell \& Co., 1812 .

Junod, Karen. Writing the Lives of Painters: Biography and Artistic Identity in Britain 1760-1810. Oxford: Oxford University Press, 2011.

Larwood, Jacob and John Camden Hotten. The History of Signboards, from the Earliest Times to the Present Day. London: John Camden Hotten, 1866.

Martinez, Cristina S. 'An Emblematic Representation of Law: Hogarth and the Engraver's Act.' In: Desmond Manderson (ed.), Law and the Visual: Representations, Technologies and Critique. Toronto: University of Toronto Press, 2018, 75-100.

Nichols, John. Biographical Anecdotes of William Hogarth; with Catalogue of His Works Chronologically Arranged; and Occasional Remarks. (Third edition, enlarged and corrected.) London: John Nichols, 1785.

Nichols, John and George Steevens. The Genuine Works of William Hogarth; Illustrated with Biographical Anecdotes, A Chronological Catalogue. Vol. II. London: Longman, Hurst, Rees, and Orme, 1810.

Nichols, J. B. (ed.). Anecdotes of William Hogarth Written by Himself: with Essays on His Life and Genius, and Criticisms on His Works, Selected from Walpole, Gilpin, J. Ireland, Lamb, Phillips, and Others. London: J. B. Nichols, 1833.

O'Connell, Sheila. 'Hogarthomania and the Collecting of Hogarth.' In: David Bindman (ed.), Hogarth and His Times. Berkeley: University of California Press, 1997.

Pope, Alexander, Jonathon Swift and John Arbuthnot. Peri Bathous: or, Martinus Scriblerus, His Treatise of The Art of Sinking in Poetry. London: B. Motte, 1727.

Pope, Alexander. The Dunciad in Four Books Printed According to the Complete Copy Found in the Year 1742. WITH THE PROLEGOMENA of SCRIBLERUS, AND NOTES VARIORUM. Book IV. London: M. Cooper, 1743.

OED. 'Bathos.' https://en.oxforddictionaries.com/definition/bathos.

Parsons, Rob. 'Famous four of Leicester Square ready to show their faces again.' Independent, 24 August 2012, https://www.standard.co.uk/news/london/famous-four-of-leicestersquare-ready-to-show-their-faces-again-8078620.html.

Princeton University. 'The Bathos.' Rare Books and Special Collections, Firestone Library, Princeton University, https://graphicarts.princeton.edu/2017/11/07/the-bathos/.

Paulson, Ronald. Hogarth's Graphic Works. (Third revised edition.) London: Print Room, 1989.

Paulson, Ronald. Hogarth: Art and Politics 1750-1764. Vol. 3. Cambridge: Lutterworth Press, 1993.

Tate. 'Hogarth 7 February—29 April 2007.' Tate Britain Exhibition, https://www.tate.org. uk/whats-on/tate-britain/exhibition/hogarth.

The Society of Sign-Painters. A Catalogue of the Original Paintings, Busts, Carved Figures. $\mathcal{E}^{2} c$. $\mathcal{E}^{2}$ c. $\mathcal{E}^{2}$. Now Exhibiting by The Society of Sign-Painters. London: T. Becket, 1762.

Thornbury, Walter. 'Leicester Square Pages 160-173.' In: Old and New London. Vol. 3. London: Cassell, Petter \& Galpin, 1878. British History Online (BHO), https://www.britishhistory.ac.uk/old-new-london/vol3/pp160-173. 
Trusler, John, John Nichols and John Ireland. The Works of William Hogarth: With Descriptions and Explanations. London: Simpson, Marshal, Hamilton, Kent \& Co., 1800.

Walford, Edward. Old and New London. Volume 6. London: Cassell, Petter \& Galpin, 1878. British History Online (BHO), https://www.british-history.ac.uk/old-new-london/vol6/ pp549-567.

Walpole, Horace. Letters from Horace Walpole to George Montagu, Esq. from the Year 1736, to the Year 1770. London: Rodwell and Martin, 1818.

West, Esme (ed.). Hogarth's House. London: Scala, 2012.

Wildgoose, Jane. 'About the Library.' The Wildgoose Memorial Library, http://www.janewildgoose.co.uk/about_the_library.html.

Wilkes, John. The North Briton from No. 1 to No. XLVI. Inclusive. London: Printed for W. Bingley, 1769 .

Wilkes, John. Encyclopadia Londinensis; or, Universal Dictionary of Arts, Sciences and Literature. Vol. II. London: J. Adland, 1810.

Worpole, Ken. Last Landscapes: The Architecture of the Cemetery in the West. London: Reaktion Books, 2003.

Websites

http://www.artandarchitecture.org.uk/images/full/585e2e2e69d8d42e9a99ea9b066 4e63138112759.html.

https://www.britishmuseum.org/research/collection_online/collection_object_details. aspx? objectId=1478456\&partId $=1$.

https://research.britishmuseum.org/research/collection_online/collection_object_ details. aspx? objectId=3050964\&partId=1.

https://www.tate.org.uk/art/artworks/hogarth-the-painter-and-his-pug-n00112.

https://www.britishmuseum.org/research/collection_online/collection_object_details/ collection_image_gallery.aspx?assetId=371796001\&objectId=3082257\&partId=1.

https://blogs.getty.edu/iris/the-ancient-origins-of-the-flower-crown/.

https://www.tate.org.uk/art/research-publications/the-sublime/lydia-hamlett-longinusand-the-baroquesublime-in-britain-r1108498.

https://williamhogarthtrust.org.uk/?page_id=705.

https://williamhogarthtrust.org.uk/?page_id=107.

https://graphicarts.princeton.edu/2017/11/07/the-bathos/.

https://www.tate.org.uk/whats-on/tate-britain/exhibition/hogarth.

\section{ABOUT THE AUTHOR}

Dr. Jane Wildgoose is an artist and researcher and Visiting Senior Research Fellow in the Centre for Life-Writing Research at King's College London. Her practice centres on collecting, memory and remembrance. She works to commission with museums and has exhibited at Kensington Palace (Historic Royal Palaces), Waddesdon Manor (Rothschild Collections/National Trust) and Sir John Soane's Museum in the UK and the Yale Center for British Art in the USA. Her recent publications include 'Post-Specimens and Present Ancestors: Passing Fables Ẽ Comparative Readings at The Wildgoose Memorial Library-An Artist's Response to the "Unique Status" of Postcolonial Human Remains in Museums', in Post-Specimen: Interobjective Encounters in Art, Science and Museology, Ed Juler and Alistair Robinson, ed. (Intellect Books, forthcoming, 2020). E-mail: wildgoose@janewildgoose.co.uk. 


\section{NOTES}

1 Junod, Karen. Writing the Lives of Painters: Biography and Artistic Identity in Britain 17601810. Oxford: Oxford University Press, 2011 (110).

2 Malone, Edmund to James Caulfield, first Earl of Charlemont (1728-1799), 18 June 1781, in O'Connell, Sheila, 'Hogarthomania and the Collecting of Hogarth.' In: Bindman, David (ed.), Hogarth and His Times. Berkeley: University of California Press, 1997 (60).

3 Hogarth's print was selected with the help of fellow convenors of the Dialogues of the Dead conference: Clare Brant, Professor of Eighteenth-Century Literature and Culture, Co-Director, Centre for Life-Writing Research and James Metcalf, doctoral research student, English Language \& Literature Department, King's College London.

4 The Tail Piece was advertised as a 'Print called FINIS, representing the Bathos or Manner of sinking in sublime Painting' in the St. James's Chronicle for 14-17 April 1762; quoted in Paulson, Ronald, Hogarth: Art and Politics 1750-1764. Vol. 3. Cambridge: Lutterworth Press, 1993 (420).

5 Wildgoose, Jane. 'About the Library,' The Wildgoose Memorial Library, http://www. janewildgoose.co.uk/about_the_library.html. Date accessed: 2 September 2019.

6 Bindman, David, 1997 (13).

7 Cust, Lionel Henry. 'Ireland, John, (d. 1808).' Dictionary of National Biography (1892), Wikisource, https://en.wikisource.org/wiki/Ireland,_John_(d.1808)_(DNB00). Date accessed: 4 September 2019.

8 Paulson, Ronald, 1993 (414); Paulson examines the relationship between Hogarth's biographical notes and the production of The Bathos in detail in the final chapter (413-39).

9 Ireland, John. Hogarth Illustrated. Vol. II. London: J. N. Boydell \& Co., 1793 (346) (italics in original).

10 'Hogarth 7 February-29 April 2007,' 'Exhibitions \& Events,' Tate, https://www.tate. org.uk/whats-on/tate-britain/exhibition/hogarth. Date accessed: 14 September 2019; Bindman, David, 1997 (201).

11 Worpole, Ken. Last Landscapes: The Architecture of the Cemetery in the West. London: Reaktion, 2003 (21).

12 Ireland, John, Vol. II, 1793 (338).

13 Idem (345-46).

14 Idem (346) (italics in original).

15 Other members of the Scriblerus Club included the poet and dramatist John Gay (16851732), the Anglo-Irish poet and clergymen Thomas Parnell (1679-1718) and the statesman Robert Harley (1661-1724).

16 For discussion of the impact of Longinus's Peri-Hypsous on the development of conceptions of the sublime in rhetoric and the visual arts, in Europe and Great Britain from the late sixteenth to the eighteenth century, see: Hamlett, Lydia, 'Longinus and the Baroque Sublime in Britain,' Tate, https://www.tate.org.uk/art/research-publications/ the-sublime/lydia-hamlett-longinus-and-the-baroque-sublime-in-britain-r1108498. Date accessed: 4 September 2019.

17 Ireland, John, Vol. II, 1793 (354) (italics in original).

18 According to John Nichols (another of the artist's key biographers in the years following the artist's death), 'the original drawing' for The Times 'was thrown by Hogarth into the fire, [but] was snatched out of it by Mrs. Lewis' (Mary Lewis [d. 1808], a cousin of Hogarth's wife) 'and is now in the possession of Mr. S[amuel]. Ireland.' Nichols, John. Biographical Anecdotes of William Hogarth; with Catalogue of His Works Chronologically Arranged; and Occasional Remarks. (Third edition, enlarged and corrected.) London: John Nichols, 1785 (386). 
19 The fleur de lys of France and the double-headed eagle of Germany may be seen hanging from the buildings in the centre of the composition.

20 The London Magazine, September 1762, quoted in Ireland, John, Vol. II, 1793, fn. (222).

21 'The sign of the last house in a row [...] used frequently to be the WORLD'S END [...] represented in various punning ways $[\ldots]$ including a $[\ldots]$ globe $[\ldots]$ with fire and smoke bursting through.' Larwood, Jacob and John Camden Hotten. The History of Signboards. London: John Camden Hotten, 1866 (461).

22 London Magazine quoted in Ireland, John, Vol. II, 1793, fn. (222).

23 William Hogarth quoted in Ireland. A Supplement to Hogarth Illustrated; Compiled from his Original Manuscripts in the Possession of John Ireland. London: Printed for the author, by G. and W. Nicol and Messrs. Boydell, 1804 (214-15, 212).

24 Bindman, David, 1997 (188); Hogarth quoted in Ireland, 1804 (215).

25 Wilkes, John. North Briton, 25 September 1762, quoted in Ireland, John, Vol. II, 1793 (206-07) (my emphasis).

26 Idem (202) (italics in original).

27 Idem (206).

28 Wilkes, John. The North Briton from No. 1 to No. XLVI. Inclusive. London: Printed for W. Bingley, 1769 (52) (italics in original).

29 Davis, Charles (ed.). 'William Hogarth: The Analysis of Beauty (London: Printed by John Reeves for the Author, 1753).' Fontes: Sources and Documents for the History of Art 1350-1750 52 (20 July 2010) 2, URL: https://archiv.ub.uni-heidelberg.de/artdok/1217/.

30 Hogarth, William. The Analysis of Beauty: A Reprint Including the Plates Formerly in Portfolio. Pittsfield: the Silver Lotus Shop, 1909 (72).

31 Bindman, David, 1997 (168).

32 Gunn, Ann V. 'The Fire of Faction Sources for Paul Sandby's Satires of 1762-1763.' Print Quarterly 24, 2017 (403).

33 Bindman, David, 1997 (174).

34 Ireland, John. Hogarth Illustrated from His Own Manuscripts. Vol. III. London: Boydell \& Co., 1812 (367).

35 Ireland, John, 1812 (279). See: Sandy, Paul, 'The Butifyer. A touch upon "The Times" plate 1,' 1904, 0819.715, British Museum, https://www.britishmuseum.org/research/ collection_online/collection_object_details.aspx?objectId=1478456\&partId=1\&searc hText=hogarth+times+1762\&page $=1$. Date accessed: 15 September 2019.

36 Nichols, John and George Steevens. The Genuine Works of William Hogarth; Illustrated with Biographical Anecdotes, a Chronological Catalogue. Vol. II. London: Longman, Hurst, Rees, and Orme, 1810 (243) (italics in original).

37 Ireland, John. Hogarth Illustrated. Vol. I. London: J. \& J. Boydell, 1793 (xcv) (italics in original).

38 Ireland, John, Vol. II, 1793 (354).

39 Idem (200).

40 Nichols, John, 1785 (93).

41 William Hogarth quoted in Ireland, 1804 (215-16).

42 Wilkes, John, 1769 (52) (italics in original).

43 Ibidem (italics in original).

44 Idem (51). Hogarth himself used hanging as a device to represent what he saw as 'the absurd misrepresentations [...] [of] some of the old masters', displayed hanging in miniature effigies on the pulpit in Enthusiasm Delineated (later reworked as Cruelty, Superstition and Fanaticism) (1762); see Ireland, John, 1812, 229.

45 Allen, Brian. 'The Society of Arts and the First Exhibition of Contemporary Art in 1760.' RSA Journal (1991) 265.

46 Larwood, Jacob, and John Camden Hotten. The History of Signboards. London: John Camden Hotten, 1866 (512). 
47 See Conlin, Jonathan. "At the Expense of the Public": The Sign Painters' Exhibition of 1762 and the Public Sphere.' Eighteenth-Century Studies 36:1 (2002) (1-21); also see Paulson, Ronald, 1993 (336-61), and Bindman, David, 1997 (194-195).

48 Ireland, John, Vol. II, 1793 (352).

49 Ibidem.

50 John Wilkes to Richard Grenville-Temple, $2^{\text {nd }}$ Earl Temple (1711-1779) quoted in Paulson, Ronald, 1993 (388). Temple, who was Pitt's brother-in-law, was a sponsor of the North Briton (374).

51 William Hogarth quoted in Ireland, John, $1812(31,112,114)$.

52 Wilkes, John, 1769 (51-2) (italics in original).

53 Ireland, John, 1812 (34).

54 Calmann, Gerta. 'The Picture of Nobody: An Iconographical Study.' Journal of the Warburg and Courtauld Institutes 23:1/2 (1960) 86, 97. See for instance Ich bin der Unschuldige Niemand (I'm the innocent Nobody), c. 1740, British Museum Collection Online, https:// research.britishmuseum.org/research/collection_online/collection_object_details. aspx? objectId=3050964\&partId=1. Date accessed: 28 March 2020.

55 The Society of Sign-Painters. A Catalogue of the Original Paintings, Busts, Carved Figures. $\mathcal{E}^{2}$ c. $\mathcal{E}$ c. $\mathcal{E}$ c. Now Exhibiting by The Society of Sign-Painters. London: T. Becket, 1762 (6) (italics in original).

56 Ireland, John, Vol. II, 1793 (346).

57 Idem (354) (italics in original).

58 Pope, Alexander. The Dunciad in Four Books Printed according to the complete Copy found in the year 1742. WITH THE PROLEGOMENA of SCRIBLERUS, AND NOTES VARIORUM. Book IV. London: M. Cooper, 1743 (156).

59 Pope, Alexander, Book I, 1743 (48-9).

60 In 1759, for instance, during a series of British military victories in what was known as the Seven Years' War, Horace Walpole (1717-1797) wrote to George Montagu (1713-1780), 'Our bells are worn threadbare with ringing the victories.' Walpole, Horace, Letters from Horace Walpole to George Montagu, Esq. from the Year 1736, to the Year 1770. London: Rodwell and Martin, 1818 (180).

61 Wilkes, John. 'Bell.' In: Encyclopedia Londinensis. London: J. Adlard, 1810 (869). John Wilkes (1750-1810), author of this encyclopædia, was a printer and bookseller, and does not appear to have been related to Hogarth's critic John Wilkes. The tolling of the church bell for the terminally ill was sufficiently common practice in the early seventeenth century for John Donne to write, in 1624, 'Perchance he for whom this bell tolls, may be so ill, as that he know not it tolls for him.' Donne, John. 'XVII. Meditation.' 'Diversions upon Emergent Occasions.' In: Henry Alford (ed.), The Works of John Donne, D. D., Dean of Saint Paul's, 1621-1631. Vol. III. London: John W. Parker, 1839 (574-75).

62 Ireland, John, Vol. II, 1793 (355).

63 Idem (356) (italics in original).

64 Idem (355); Bindman, David, 1997 (187).

65 Trusler, John, John Nichols and John Ireland. The Works of William Hogarth: With Descriptions and Explanations. London: Simpson, Marshal, Hamilton, Kent \& Co., 1800 (317). Cristina S. Martinez provides a detailed analysis of the symbolism of 'the abandoned crown in pieces' in The Bathos, comparing it with the shining crown depicted in Crowns, Mitres, Maces, $\mathcal{E}^{2} c$. and arguing that, as one of the 'visible emblems of royal authority,' the broken crown 'attests to the fading royal mystique and presents a discouraging scene in which law and justice have left the earth.' See: Martinez, Cristina S. 'An Emblematic Representation of Law: Hogarth and the Engraver's Act.' In: Desmond Manderson (ed.), Law and the Visual: Representations, Technologies and Critique. Toronto: University of Toronto Press, 2018 (80, 85). 
66 Trusler, John, John Nichols and John Ireland, 1800 (317).

67 Wilkes, John, 1769 (52) (italics in original).

68 Ireland, John, Vol. II, 1793 (356) (italics in original).

69 Idem (355) (italics in original). The figure of a man on horseback depicted on the seal has been interpreted as a representation of Death (Paulson; Bedenk); it bears a close resemblance to the Great Seal of the Realm (used by the King to authorise important State documents), which featured the monarch on horseback on its reverse side; this may be a reference to the seal that would have been attached to the Letters Patent appointing Hogarth Sargeant-Painter to the King, George II (1683-1760) in 1757. See: 'Seals,' fig. 5 and fig. 6, eighteenthcenturylit, http://eighteenthcenturylit.pbworks. com/w/page/102406330/Seals. Date accessed: 16 September 2019.

70 William Hogarth quoted in Ireland, A Supplement, 1804 (217).

71 Ireland, John, Vol. II, 1793 (356-57).

72 Pope, Alexander, Book I, 1743 (41).

73 Pope, Alexander, Book IV, 1743 (208).

74 Vanitas: a type of still-life composition, popular in the Netherlands in the seventeenth century, depicting arrangements of objects emblematic of the brevity of life and the emptiness of worldly pleasures, intended to promote meditation on mortality. The term vanitas derives from the Book of Ecclesiastes 1:2-11: 'Vanity of vanities, saith the Preacher, vanity of vanities; all is vanity' (that is, empty).

75 Calmann, Gerta, 1960 (97).

76 Pope, Alexander, Book I, 1743 (48).

77 Hogarth, William, 1909 (157).

78 Wilkes, John, 1769 (52).

79 Paulson, Ronald. Hogarth's Graphic Works. (Third revised edition.) London: Print Room, 1989 (cat. 216), quoted in 'The Bathos.' 'Graphic Arts Collection,' Rare Books and Special Collections, Firestone Library, Princeton University, https://graphicarts.princeton.edu/2017/11/07/the-bathos/. Date accessed: 5 September 2019.

80 Ibidem.

81 Bindman, David, 1997 (201).

82 Ibidem.

83 Paulson, Ronald, 1993 (416).

84 Junod, Karen, 2011 (110).

85 Bindman, David, 1997 (201).

86 Ireland, John, Vol. I, 1793 (cx).

87 Nichols, J. B. (ed.). Anecdotes of William Hogarth Written by Himself: with Essays on His Life and Genius, and Criticisms on His Works, Selected from Walpole, Gilpin, J. Ireland, Lamb, Phillips, and Others. London: J. B. Nichols, 1833 (316).

88 Ireland, John, Vol. I, 1793 (cxi).

89 Carruthers, Emilie. 'Origins of the Flower Crown.' 'The Iris: Behind the Scenes of the Getty,' Getty Institute, May 4, 2017, https://blogs.getty.edu/iris/the-ancient-origins-ofthe-flower-crown/. Date accessed: 11 September 2019.

90 See West, Esme, 2012 (25); also see: 'Letters Patent, 1757 purchased,' William Hogarth Trust, https://williamhogarthtrust.org.uk/?page_id=107. Date accessed: 5 October 2019.

91 Bindman, David, 1997 (201).

92 West, Esme, 2012 (35).

93 Prints of Hogarth's tomb in Chiswick Churchyard were published in 1795, 1817, and 1823; a print of the tomb accompanied a review of The Works of William Hogarth in the Gentleman's Magazine in November 1822 (425-427); see: Nichols, J. B. (ed.), 1833 (315). 
94 Walford, Edward. Old and New London. Volume 6. London: Cassell, Petter \& Galpin, 1878. 'Chiswick Pages 549-67.' 'Chapter XL Chiswick.' British History Online (BHO), https://www.british-history.ac.uk/old-new-london/vol6/pp549-567. Date accessed: 11 September 2019.

95 'Hogarth and Chiswick.' William Hogarth Trust, https://williamhogarthtrust.org. uk/?page_id=36. Date accessed: 29 September 2019.

96 West, Esme, 2012 (37); also see: 'Hogarth’s House.' William Hogarth Trust, https:// williamhogarthtrust.org.uk/?page_id=705. Date accessed: 28 September 2019.

97 Thornbury, Walter. 'Leicester Square Pages 160-173.' In: Old and New London. Vol. 3. London: Cassell, Petter \& Galpin, 1878. British History Online (BHO), https://www. british-history.ac.uk/old-new-london/vol3/pp160-173.Dateaccessed:28September2019.

98 Ibidem.

99 The bust of Hogarth was one of four, of former residents including John Hunter (1728-1793), Isaac Newton (1643-1727) and Joshua Reynolds (1723-1792), located in Leicester Square as part of landscaping in 1874. Parsons, Rob, 'Famous four of Leicester Square ready to show their faces again.' Independent, 24 August 2012, https:// www.standard.co.uk/news/london/famous-four-of-leicester-square-ready-to-showtheir-faces-again-8078620.html. Date accessed: 28 September 2019. Brown, David, 'Statues effaced by acid clean.' The Guardian, 23 October 2002, https://www.theguardian.com/uk/2002/oct/23/localgovernment.arts. Date accessed: 28 September 2019. On a recent visit to Leicester Square (28 September 2019) there was no sign of the busts of Hogarth, Hunter, Newton or Reynolds.

100 Ireland, John, Vol. I, 1793 (cxi).

101 Harrison, Robert Pogue. The Dominion of the Dead. Chicago: University of Chicago Press, 2003 (x) (italics in original).

102 Paulson, Ronald, 1993 (416).

103 Bindman, David, 1997 (201).

104 Harrison, Robert Pogue, 2003 (39). 